\title{
The Socioeconomic Impact of a Customized Lending Program for Furniture Clusters in Chiniot, Punjab
}

\author{
Sajjad Mubin, Shazia Mudassir Ali, M. Ubaid Iqbal*
}

\begin{abstract}
This study evaluates a Punjab Government development project titled "Customized Lending Program for Furniture Cluster at Chiniot." The project was implemented by the Punjab Government's Small Industries Corporation at a total cost of PRs 40 million: the sum of PRs 100,000 was loaned to 400 small and medium furniture manufacturers in Chiniot, to be repaid in 22 equal monthly installments with a grace period of two months. The socioeconomic impact of the loan was determined from data collected through a survey. Overall, the project was deemed unsuccessful: on average beneficiaries' income fell due to negative factors such as power outages and the fact that uniform loans were made to small and larger manufacturers.
\end{abstract}

Keywords: Punjab development project, Chiniot, impact evaluation, furniture industry, microfinance, Pakistan.

\section{JEL classification: $\mathrm{O} 10$.}

\section{Introduction}

The district of Chiniot in Punjab is well known for producing master-crafted furniture, most of which is produced by artisans known locally as tarkhans and lohars. Periodically, the government has initiated development projects to improve the quality and quantity of furniture trade in the area. The Wooden Furniture Common Facility Services Centre and Show Room (WFCFSC) was established in 2007 to provide financial and technical assistance to manufacturers in furniture design, wood seasoning techniques, and showroom display. In 2008, the Punjab government initiated a project titled "Customized Lending Program for Furniture Cluster at Chiniot." Under this project, a total of PRs 40 million was made available to furniture manufacturers in the form of instant loans. With a three-year gestation period, the project was designed to provide easy access to credit for Chiniot's small furniture industry through marketdriven credit support.

\footnotetext{
* Planning and Development Department, Government of Punjab, Lahore, Pakistan.
} 
The characteristics of this credit support scheme are as follows (see Punjab, Industries, Commerce, and Investment Department, 2008, 2012):

- Each manufacturing unit was provided a loan of PRs 100,000.

- A one-time processing fee (administrative charges) of PRs 6,000 was charged (at the rate of 6 percent of the loan amount) with no other financial costs.

- The loan was to be repaid in 22 equal monthly installments with a grace period of two months.

- A late payment penalty fee was to be charged at the rate of PRs 500 per month on each installment.

- Extensive documentation was involved in the loan processing as a guarantee of repayment.

The project was executed by the Punjab Small Industries Corporation (PSIC) under the Punjab government at a total cost of PRs 40 million. The selected 400 beneficiaries were small to medium furniture manufacturers. In all, more than 1,000 small, medium, and large units were identified, but larger manufacturers were obviously uninterested in a PRs 100,000 loan, given the small tradeoff involved. No other project dealing with microfinance or any other grant-in-aid or subsidy for budgetary support had been initiated in the previous five years.

Borrowers were identified by the PSIC on the basis of uniform criteria: all were small to medium workshop owners employing, on average, six to eight artisans or workers, most of who were poorly paid or even unpaid, if apprentices. Although PRs 100,000 is not a significant loan amount in this context, constrained funds for development in this sector meant that only PRs 40 million could be allocated to the project. Nonetheless, the amount was deemed sufficient to purchase materials and pay bills and wages to run the business sustainably.

Borrowers used the loan money to purchase wood materials, small tools, and molder machines and to pay their artisans. It was assumed that the loan would help beneficiaries prosper financially and socioeconomically - a hypothesis this study seeks to test.

\section{Literature Review}

The systematic evaluation of development projects and programs was conceived and formalized in the 1960s by donor agencies to assess 
their performance and impact (Baker, 2000). Rossi and Freeman (1993) define evaluation as "the systematic application of social research procedures for assessing the conceptualization, design, implementation, and utility of ... programs." Patton (1997) has introduced utilizationfocused evaluations on the premise that evaluations should be judged by their utility and actual use. Mubin, Ahmed, and Sial (2011) argue that the purpose of project evaluation is not fulfilled unless it is critically utilized as feedback in planning and decision-making. The evaluation methodology for this study was developed based on research conducted by Mubin, Ahmed, Ahmed, and Mubin (2013) and Mubin, Ahmed, Mubin, and Majeed (2013).

A wide range of microfinance development projects has been initiated by national and international donor agencies across the developing world, but with mixed results. In Bangladesh, the microfinance model presented by Dr Muhammad Yunus was successfully implemented and reported to be a high-impact intervention. However, in Pakistan, similar results could not be achieved: the microfinance (instant loan) components introduced under the Sustainable Livelihood of Barani Areas Project or the Socioeconomic Impact in Destitute and Neglected Children Families project, for instance (see Sial, 2011, 2012), did not meet their desired targets.

\section{Methodology}

Apart from improving the financial and socioeconomic wellbeing of small furniture manufacturers in Chiniot, the project was expected to contribute to employment generation and training, thus ensuring the sustainable development of this cluster. For the purpose of this study, we also assume that any sort of socioeconomic impact on the target beneficiaries was solely due to the intervention under study.

Over 3,300 furniture-manufacturing units - most of which rely on fairly basic technology - exist in and around Chiniot. Of these, 400 units that met the identification criteria were financed though this credit support scheme. A single manufacturing unit (furniture workshop) was taken as the unit of analysis. All manufacturing units were selected at random and divided into a treatment group and a control group.

These 400 manufacturing units or subprojects benefited directly from the credit support facilities provided by the project. Their average net income was PRs 10,000 to 40,000 per month, in a few cases approaching 
PRs 50,000 or more. Due to time and cost constraints, it was not possible to visit all the manufacturing units in the treatment group. Therefore, 7.5 percent $(=30)$ manufacturing units were randomly selected out of the total 400 beneficiaries. In order to obtain a representative sample from among all the units, each was assigned a unique number (from 001 to 400), following which a random sample of 30 units was selected electronically using a random number generator.

The survey questionnaire was designed to measure the impact of the project on all the project's components, including loan terms and conditions, employment generation, machinery and equipment, and institutional and implementation support. Table 1 describes the indicators used to measure progress against the project's objectives. The input received from each beneficiary was recorded against the indicators, with Punjabi and Urdu used as the survey medium.

Table 1: Project impact indicators

\begin{tabular}{|c|c|}
\hline Indicator & Description \\
\hline $\begin{array}{l}\text { Turnover, income } \\
\text { generation, overall impact } \\
\text { and satisfaction level of } \\
\text { beneficiaries }\end{array}$ & $\begin{array}{l}\text { - Change in annual turnover (before/after) } \\
\text { - Income generation (before/after) } \\
\text { - Overall impact of loan on business } \\
\text { (before/after) } \\
\text { - Overall satisfaction level }\end{array}$ \\
\hline Education & $\begin{array}{l}\text { - Number of children attending school or } \\
\text { seminary (before/after) } \\
\text { - Monthly expenditure on schooling } \\
\text { (before/after) } \\
\text { - School type (before/after) }\end{array}$ \\
\hline Vehicle ownership & $\begin{array}{l}\text { - Number of entrepreneurs who own a (i) loader } \\
\text { truck, (ii) Bolan pickup, (iii) car, (iv) motorcycle, } \\
\text { (v) bicycle, or (vi) animal-driven cart } \\
\text { (before/after) }\end{array}$ \\
\hline $\begin{array}{l}\text { Machinery type (manual or } \\
\text { electrical) }\end{array}$ & $\begin{array}{l}\text { Number of persons who own a (i) cutter, (ii) } \\
\text { molder, (iii) planner, or (iv) electrical } \\
\text { equipment (before/after) }\end{array}$ \\
\hline $\begin{array}{l}\text { Employment generation } \\
\text { (paid employees only) }\end{array}$ & $\begin{array}{l}\text { - } 0 \text { employees (before/after) } \\
\text { - } 1-4 \text { employees (before/after) } \\
\text { - } 4-8 \text { employees (before/after) } \\
\text { - } 8-12 \text { employees (before/after) } \\
\text { - } 12 \text { or more employees (before/after) }\end{array}$ \\
\hline
\end{tabular}




\begin{tabular}{ll}
\hline Indicator & \multicolumn{1}{c}{ Description } \\
\hline Building ownership & - Own building (before/after) \\
& - Family-owned (before/after) \\
& - Partnership/rented (before/after) \\
& - Others (before/after) \\
Living standards (basic & - Owns residence (before/after) \\
facilities) & - Use of home appliances (fridge, AC, television, \\
& computer, washing machine) (before/after) \\
& - Electricity, gas, and water (before/after) \\
& - Toilet (before/after) \\
\hline
\end{tabular}

A comprehensive list giving details of each beneficiary - including their name, address, telephone numbers, workshop address, products manufactured, and loan details - was made available. The purpose of visiting these workshops was to verify the information reported. Different features of the project were inspected in order to validate the accruing benefits.

\section{Results and Discussion}

The most important indicator from the firm's point of view is annual turnover. Our results found that on the case of this project, firms' annual turnover decreased, implying that the project failed from a business point of view. The reasons for this are discussed below.

\subsection{Turnover, Income Generation, Satisfaction Level and Overall Impact}

Table 2 shows a slight negative trend in respondents' annual turnover before and after the intervention, from an average of PRs 1.179 million to PRs 1.176 million, respectively.

Table 2: Annual turnover before and after project (PRs)

\begin{tabular}{lcc}
\hline Statistic & Annual turnover pre-2008 & Annual turnover post-2012 \\
\hline Mean & $1,179,066.67$ & $1,175,853.33$ \\
Minimum & $24,000.00$ & $36,000.00$ \\
Maximum & $24,300,000.00$ & $24,300,000.00$ \\
\hline
\end{tabular}

Source: Author's calculations

Respondents cited a number of issues that reduced the project's efficacy from their perspective (Table 3), including difficult loan terms and conditions, excessive documentation needed for loan processing, penalties 
on late installment deposits, and the fact that a uniform amount (PRs $100,000)$ was lent across all units, irrespective of business scale (larger units, for example, felt that the loan should have been at least PRs 300,000).

Table 3: Satisfaction with terms and conditions of loan and recovery schedule (percent)

\begin{tabular}{lcc}
\hline \multicolumn{1}{c}{$\begin{array}{c}\text { Are you satisfied with the loan terms and } \\
\text { conditions, and recovery schedule? }\end{array}$} & No & Yes \\
\hline Amount of loan & 57 & 43 \\
Processing fee & 47 & 53 \\
Documentation & 63 & 37 \\
Number of installments & 20 & 80 \\
Penalties (PRs 500/month) & 73 & 27 \\
Customer care & 16 & 84 \\
Processing mechanism/time & 83 & 17 \\
Recovery follow-up issues & 26 & 74 \\
Facilities at center & 7 & 93 \\
PSIC staff are unbiased/employ fair practices & 10 & 90 \\
\hline
\end{tabular}

Source: Author's calculations

As far as any overall improvement in business is concerned, only 10 percent of respondents reported that the loan had had a high impact on business growth. Most respondents (63 percent) felt the project had had a medium impact, while 17 percent and 10 percent indicated little or no impact, respectively (Figure 1).

Figure 1: Impact of loan on business

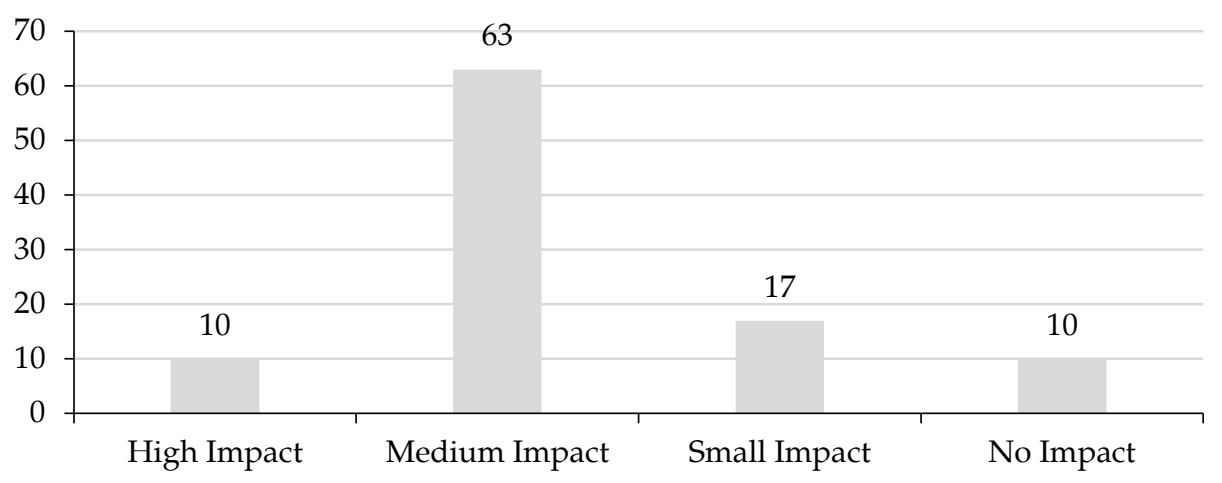

Source: Author's calculations 
Additionally, exogenous factors such as constant power outages and, in turn, reduced working hours, meant that many artisans were less productive than expected. This prevented workshops from fully exploiting the benefits of the capital they had been loaned. Figure 2 indicates that the average monthly income of project beneficiaries fell from PRs 24,625 to PRs 20,608 before and after the intervention, respectively.

\section{Figure 2: Change in average monthly income}

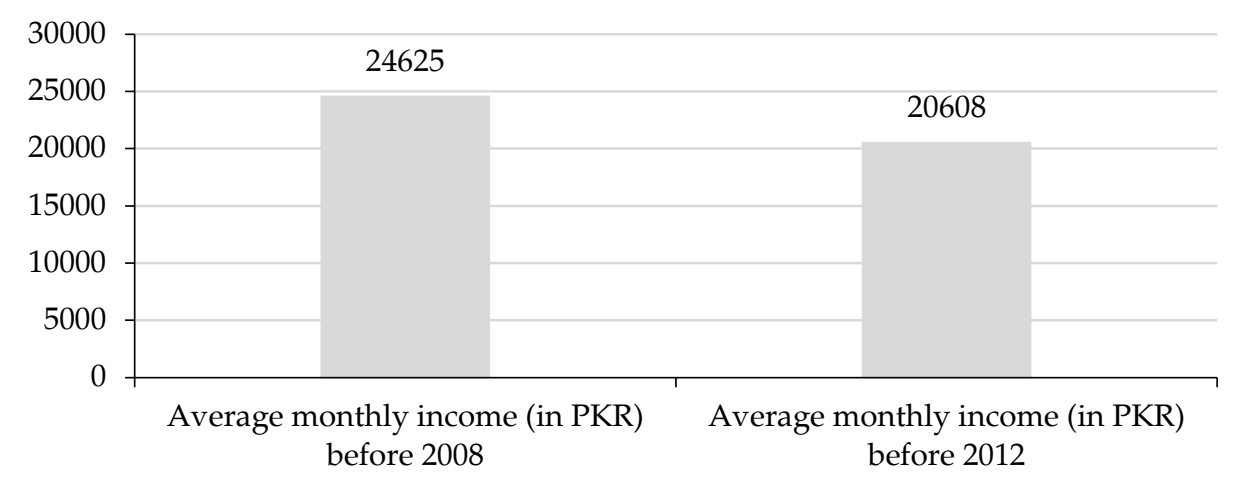

Source: Author's calculations

Apart from the high cost of power and power outages, some respondents suffered business losses as a result of low-quality raw material, that is, those using sheesham wood found part of their supply to be diseased. Moreover, respondents reported that the loan amount was not enough to purchase more than basic machines such as molders or artisans' tools. Their remaining work was carried out using rented machines, which implied that the cost of production remained led to the project having a negative impact on firm level income.

Overall, these factors combined led to the project having a negative impact on firm level income. While it is possible that the project may have had a positive impact in the absence of negative business factors, the fact remains that the loan remained ineffective, with many borrowers finding it difficult to repay their loan installments on time.

\subsection{Schooling Choices}

The project's impact on education was measured by the number of school-going children on the assumption that families who sent their children to private schools were financially better off than those who sent 
their children to government schools. The number of private school-going children per family among project beneficiaries fell from 53.3 to 43.3 percent over the course of the intervention (Figure 3).

\section{Figure 3: Children attending private schools}

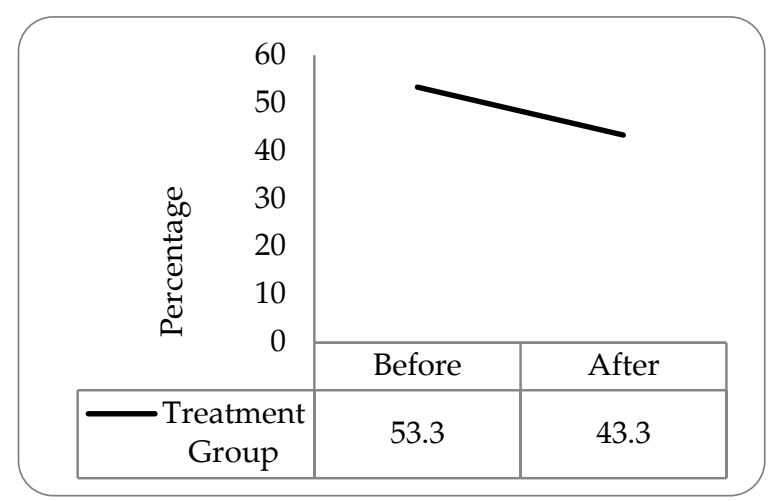

Source: Author's calculations

The proportion of children attending government schools, however, increased from 16.6 to 33.3 percent, while that of children attending seminaries rose by 3 percent (Figure 4). This could imply that households' capacity to bear schooling expenditure was reduced. Alternately it is possible that household's confidence in Government School's increased. A rise in seminary enrolment may effect that project beneficiaries were less able to afford to send their children to private or public schools. Our results imply that the microcredit scheme had a negative socioeconomic impact in terms of better schooling choices.

Figure 4: Children attending seminaries

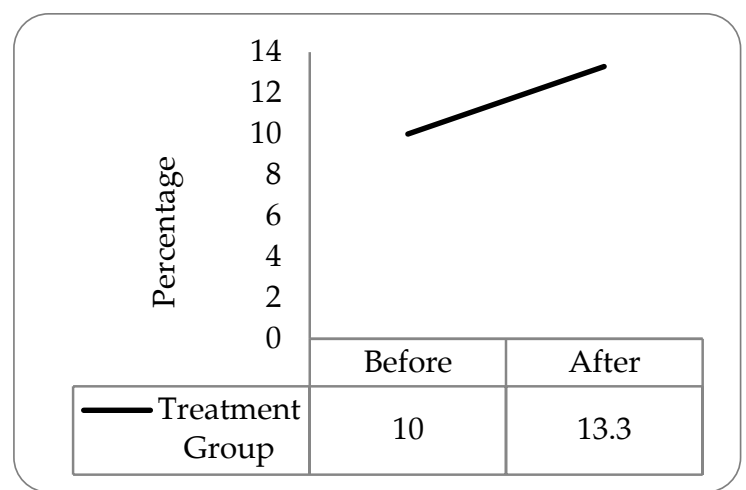

Source: Author's calculations 


\subsection{Business Logistics and Transportation}

The use of motorcycles rather than bicycles was employed as an indicator of increased business income - and, therefore, of better living standards - among the respondents. Some reported having bought motorcycles or even pickup vehicles to replace their previous modes of transport. About 3 percent owned a loader truck before and after the intervention, indicating no change in business growth. The percentage of beneficiaries using a motorcycle rose from 70.1 to 76.9 percent, while the use of bicycles decreased from 23.3 to 16.6 percent (Figures 5 and 6).

Figure 5: Entrepreneurs who use a motorcycle

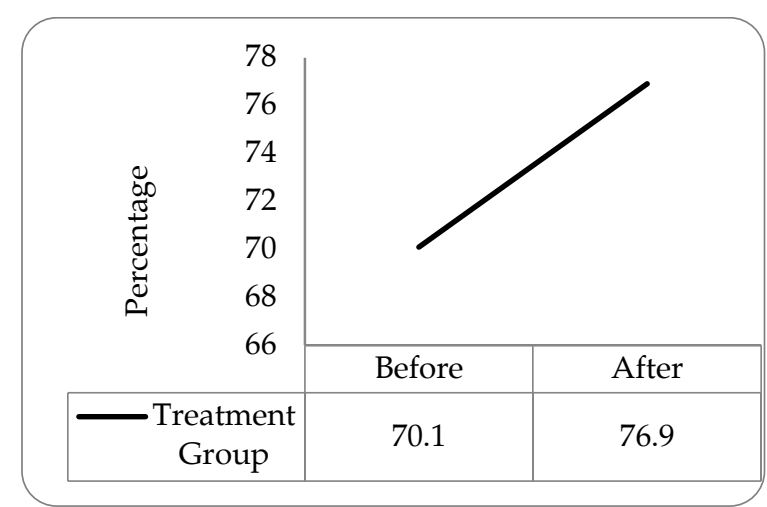

Source: Author's calculations

Figure 6: Entrepreneurs who use a bicycle

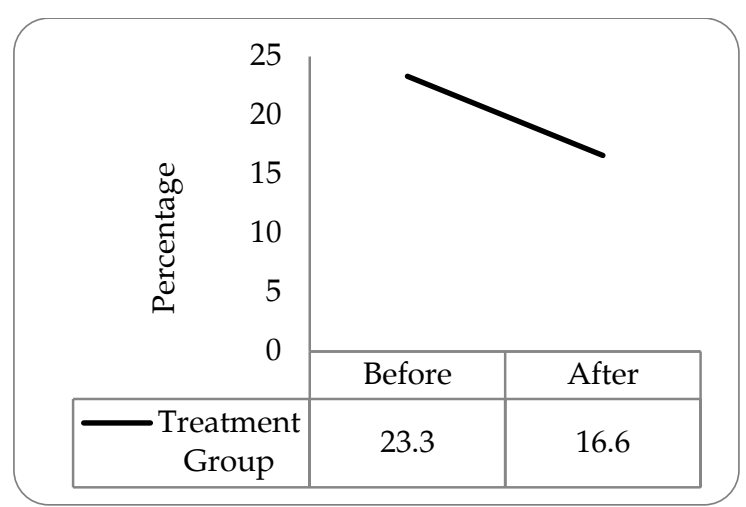

Source: Author's calculations 


\subsection{Machinery Type and Ownership}

One of the objectives of the credit support scheme was to encourage the use of efficient machinery and equipment in the furniture industry. Ownership of molder machines among project beneficiaries increased from 75.9 to 93.1 percent during the project, while that of planner machines rose from 86.7 to 90 percent. About 43.3 percent of artisans reported using planner machines before the scheme; this rose to 46.7 percent postintervention. Most respondents said they had used the loan money to buy molder machines because it did not cover the cost of other, more expensive, machinery. The percentage of respondents who had adopted electrical equipment increased from 70 to 73.3 percent during the project.

\subsection{Employment Generation}

A key objective of this project was to generate employment among skilled artisans. The percentage of respondents employing unpaid labor (as apprentices) fell from 16.7 to 10 percent. The percentage of furniture workshops employing one to four paid artisans increased from 46.7 to 73.3 percent, while that of workshops employing four to eight paid artisans remained constant at 26.7 percent before and after the intervention.

\subsection{Business Building Ownership}

Ownership of workshop premises is key to business growth and stability, contributing to annual turnover and serving as a gauge of capital investment and profit margins. The percentage of furniture manufacturers who owned their workshops increased from 36.7 to 46.7 percent during the project (Figure 7). Conversely, the percentage of manufacturers operating from family-owned workshop premises decreased from 20 to 16.5 percent.

Figure 7: Business building ownership (self-owned)

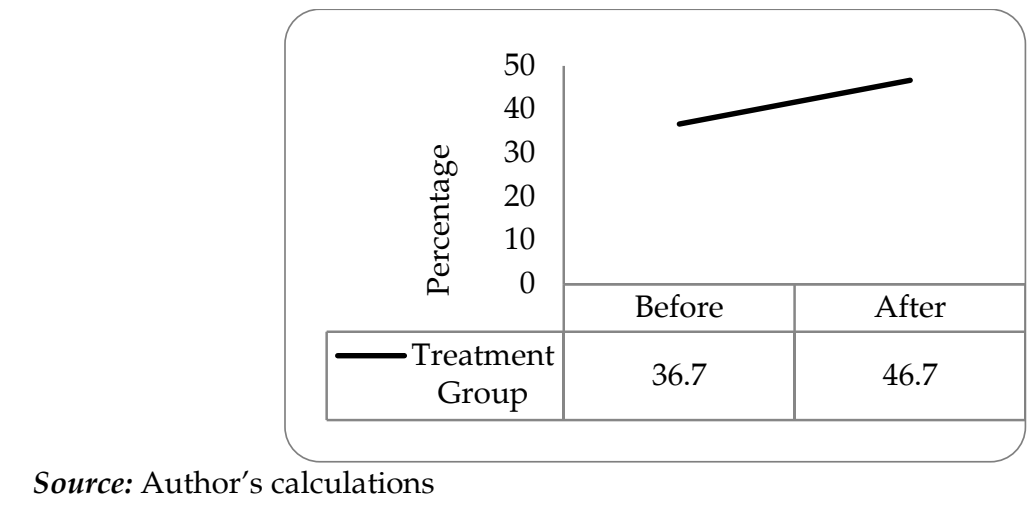


The trend of establishing new workshops rather than working from family-owned premises has improved over the years. The study also found that the percentage of furniture manufacturers with rented workshops decreased from 43.3 to 36.7 percent during the project (Figure 8).

Figure 8: Business building ownership (partnership/rented)

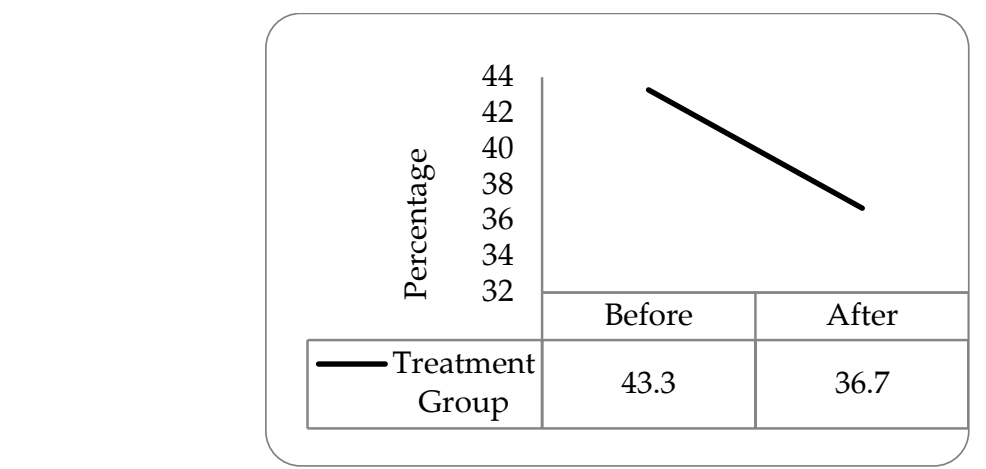

Source: Author's calculations

This indicates that such businesses have not grown, with partnerships declining perhaps as a result of limited growth opportunities. In family-owned businesses, beyond a certain level, the entrepreneur's son often becomes an independent entrepreneur as business improves, which serves to decentralize the family business. In this case, however, family dependence has increased, implying limited business growth during the time frame of the project.

\subsection{Living Standards and Access to Basic Facilities}

Another indicator of business improvement is a rise in living standards, which underscores the indirect impact of the credit scheme on households that benefited from the loan. These indicators include ownership of residence, a vehicle, and home appliances such as an air conditioner, fridge, television, and washing machine. The percentage of respondents living in a self-owned residence increased from 47.6 to 48.5 percent, while that of respondents who owned a vehicle increased from 86.6 to 90 percent (Figure 9). Ownership of home appliances remained constant at 96.6 percent (Figure 10).

Table 4 shows that despite the significant shortcomings of the project, there were positive increases in some indicators. 


\section{Figure 9: Entrepreneurs who own a vehicle}

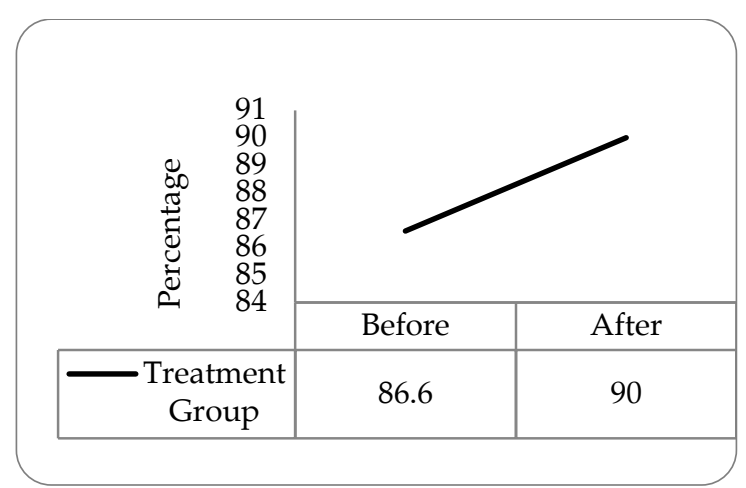

Source: Author's calculations

Figure 10: Entrepreneurs who own basic household appliances

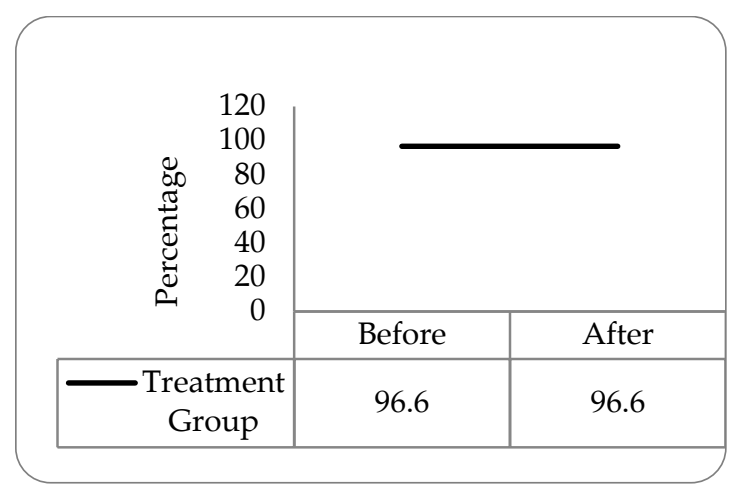

Source: Author's calculations 
Table 4: Impact summary of intervention

\begin{tabular}{lc}
\hline Indicator & $\begin{array}{c}\text { Simple difference/ pre- and } \\
\text { post- method }\end{array}$ \\
\hline Average annual income of beneficiaries & -7.4 \\
Private school & -10.0 \\
Government school & 16.7 \\
Seminary & 13.3 \\
Loader truck & 0.0 \\
Motorcycle & 6.8 \\
Cycle & -6.7 \\
Electric cutter & 3.3 \\
Molder & 17.2 \\
Planner & 3.3 \\
Drill machine & 6.7 \\
Unpaid labor & -6.7 \\
Paid labor (1-4 employees) & 26.6 \\
Paid labor (4-12 employees) & 0.0 \\
Workshop building (self-owned) & 10.0 \\
Workshop building (family-owned) & -3.5 \\
Workshop building (rented) & -6.6 \\
Residence (self-owned) & 0.9 \\
Transportation (self-owned) & 3.4 \\
Use of home appliances & 0.0 \\
\hline
\end{tabular}

Source: Author's calculations

\section{Recommendations}

The results show that the sponsoring and executing agencies concerned need to analyze why the government's project did not achieve its desired economic impact. The story that emerges is that the design parameters and the project methodology need to be improved. The executing agency must also consider why borrowers were not satisfied with the microcredit scheme. Some of the major recommendations based on the results of this analysis are as follows:

First, the loan amount should be more flexible, based on the requirements and credit rating of borrowers, and range from PRs 100,000 to PRs 300,000. The 6 percent processing fee should be reversible at the time of submission of the last loan installment. 
Second, the loan process should be made easier and omit the need for unnecessary documentation. The late payment fine should also be removed from the project design and replaced by other ways of ensuring timely loan repayment by beneficiaries.

Third, there is a large gap between the socioeconomic conditions of different scales of furniture manufacturing. Most entrepreneurs are small and not well connected with the bigger markets. For such projects to be efficient, small furniture manufacturers should be targeted first and given preference when disbursing loans.

Fourth, the furniture industry's workforce needed professional training and certification. Credit support or direct subsidiary schemes will not only help improve socioeconomic conditions among craftsmen in the furniture industry of Chiniot, but also preserve cultural heritage and traditional skills.

\section{Conclusions}

Our analysis of the project yields the following conclusions:

First despite the provision of a customized credit support facility, the annual turnover and average net annual income of the targeted beneficiaries fell. Frequent and excessive power outages may explain the incidence of idle labor and loss of opportunity cost in terms of capital and equipment, as a result of which the project failed to meet its main objectives.

Second most respondents (63 percent) felt that the project had had only a medium impact on business growth; 17 and 10 percent reported little or no impact, respectively. More than half were not satisfied with the loan amount, the fine on late payment, laborious documentation procedures, and loan processing time. This again shows that the project did not meet its objectives.

Third the proportion of beneficiaries' children attending a government school increased significantly while that of children enrolled in a private school was reduced. This was probably because households found it difficult to bear the costs of private schools (perhaps due to falls in income, increased private school fees, or combination of both).

Fourth the project led to an increased usage and ownership of semiautomatic electricity-driven equipment. Though one objective of the project was to increase productivity and the adoption of automatic machines could have potentially led to this, it seems that the beneficiaries were affected adversely by power outages, which affected their production 
and annual income. Also, most project beneficiaries were small entrepreneurs who had owned a bicycle prior to receiving the loan. The survey revealed that bicycle ownership decreased while motorcycle ownership increased during the project period - this was seen as a positive impact. Most beneficiaries reported purchasing motorcycles to make their manufacturing operations more efficient.

Also, the percentage of unpaid labor (apprentices) fell and that of manufacturing units employing one to four paid artisans (in the treatment group) increased. The latter impact was likely driven by market and social demand. At the same time self-ownership of furniture workshop premises improved after the intervention. Also, ownership of personal transportation and basic household appliances remained constant before and after the intervention.

Overall, the government's project was unsuccessful: The average income among furniture units fell though this may be due to overall negative business factors such as power outages, especially during summer, which is peak business season. Also another weakness in the project was the fact that uniform loans were provided irrespective of the manufacturer's scale of business.

Our results imply that such microfinance schemes are feasible if designed with softer terms and conditions, and if beneficiaries concerns are better addressed. 


\section{References}

Baker, J. L. (2000). Evaluating the impact of development projects on poverty. Washington, DC: World Bank.

Mubin, S., Ahmed, M., Ahmed, J., \& Mubin, G. (2013). Mid-term evaluation through a tested survey design of project "Afforestation of blank areas in state forest of Murree hills. Pakistan Journal of Science, 65(1), 5-10.

Mubin, S., Ahmed, M., Mubin, G., \& Majeed, M. A. (2013). Impact evaluation of development projects: A case study of project "Development of sericulture activities in Punjab." Pakistan Journal of Science, 65(2), 263-268.

Mubin, S., Ahmed, M., \& Sial, J. (2011). Terminal evaluation of public sector development projects: An analysis of 85 evaluated development projects of Punjab province. Pakistan Journal of Engineering and Applied Sciences, 9, 58-67.

Patton, M. Q. (1997). Utilization-focused evaluation: The new century text (3rd ed.). Los Angeles, CA: SAGE Publications.

Punjab, Industries, Commerce, and Investment Department. (2008). Customized lending program for furniture cluster at Chiniot (PC-I). Lahore: Author.

Punjab, Industries, Commerce, and Investment Department. (2012). Customized lending program for furniture cluster at Chiniot (PC-IV). Lahore: Author.

Rossi, P. H., \& Freeman, H. E. (1993). Evaluation: A systematic approach. Los Angeles, CA: SAGE Publications.

Sial, J. (2011). Third-party validation report of socioeconomic development of destitute and neglected children families. Lahore: Directorate General Monitoring and Evaluation.

Sial, J. (2012). Evaluation report of sustainable development in barani areas project. Lahore: Directorate General Monitoring and Evaluation. 